\title{
Research Furthers Conservation of Grand Canyon Sandbars
}

Grand Canyon National Park (fig. 1) lies approximately $25 \mathrm{~km}$ (15 mi) downriver from Glen Canyon Dam, which was built on the Colorado River just south of the Arizona-Utah border in Glen Canyon National Recreation Area (fig. 2). Before the dam began to regulate the Colorado River in 1963, the river carried such large quantities of red sediment, for which the Southwest is famous, that the Spanish named the river the Rio Colorado, or "red river." Today, the Colorado River usually runs clear below Glen Canyon Dam because the dam nearly eliminates the main-channel sand supply (Topping and others, 2000b; Wright and others, 2005). The daily and seasonal flows of the river were also altered by the dam (Topping and others, 2003). These changes have disrupted the sedimentary processes that create and maintain Grand Canyon sandbars. Throughout Grand Canyon, sandbars create habitat for native plants and animals, supply camping beaches for river runners and hikers, and provide sediment needed to protect archaeological resources from weathering and erosion (Rubin and others, 2002; Wright and others, 2005).

Maintenance of sandbars in the Colorado River ecosystem, the river corridor that stretches from the dam to the western boundary of Grand Canyon National Park, is a goal of the Glen Canyon Dam Adaptive Management Program (U.S. Department of the Interior, 1995; Patten and others, 2001). The program is a federally authorized initiative to ensure that the mandates of the Grand Canyon Protection Act of 1992 are met through advances in information and resource management.

The U.S. Geological Survey's Grand Canyon Monitoring and Research Center has responsibility for scientific monitoring and research efforts for the program. Extensive research and monitoring during the past decade have resulted in the identification of possible alternatives for operating Glen Canyon Dam that hold new potential for the conservation of sand resources.

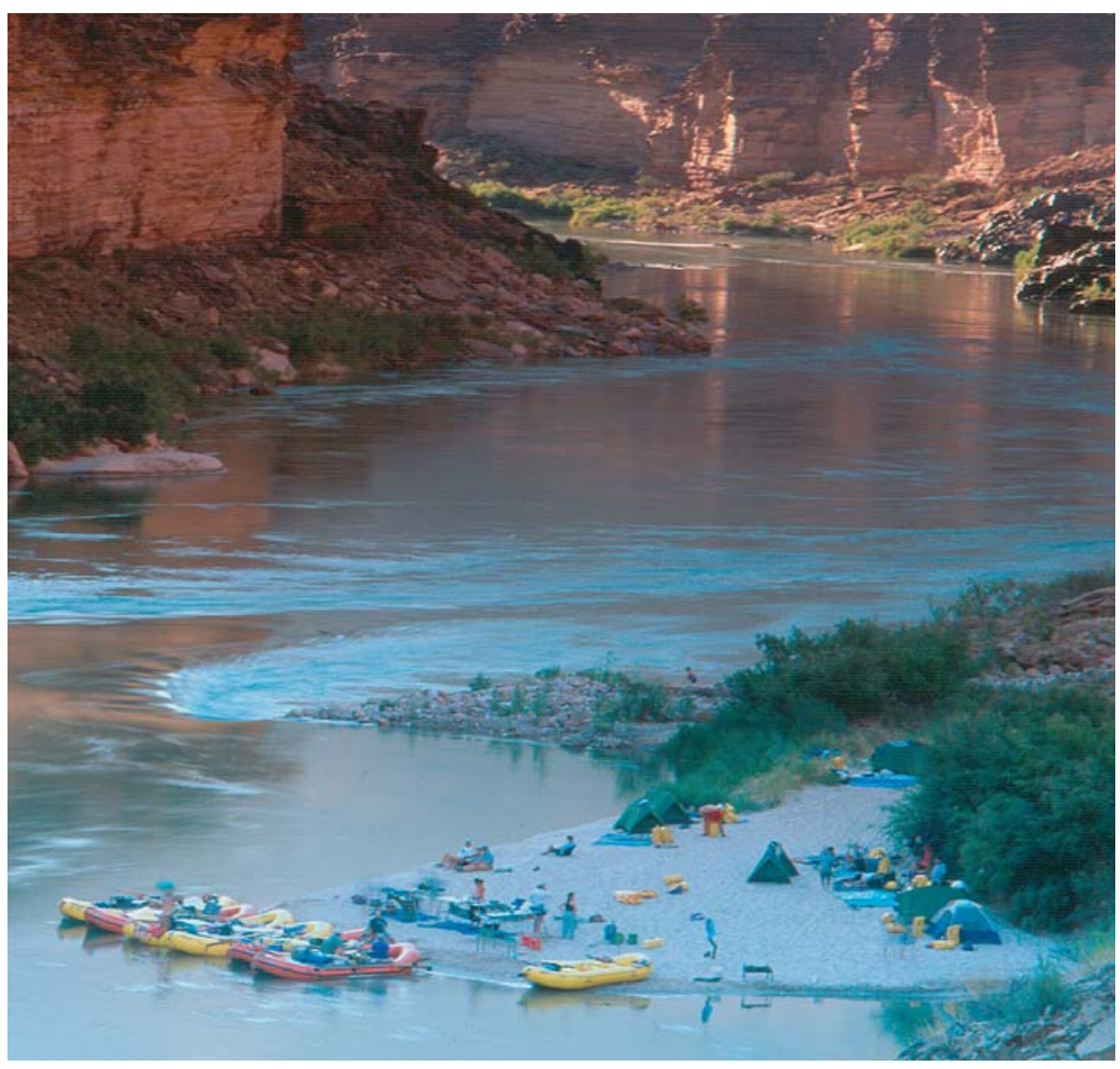

Figure 1. Sandbars in Grand Canyon create habitat for native plants and animals, supply camping beaches for river runners and hikers, and provide sediment needed to protect archaeological resources from weathering and erosion. Photograph ${ }^{\odot} 2005$ Geoff Gourley; used with permission.

\section{Sand in Grand Canyon}

Tributaries to the Colorado River below Glen Canyon Dam, such as the Paria and Little Colorado Rivers, provide the only new inputs of sediment that can be used to maintain sandbars in the Colorado River ecosystem in the postdam era (fig. 3). Smaller tributaries are also responsible for debris-fan eddy complexes, the ecosystem's dominant landforms (Schmidt and Graf, 1990; Schmidt and Rubin, 1995). A debris fan is a triangular landform that is created when a tributary deposits gravel-sized and larger particles at its intersection with the Colorado River during seasonal floods. Debris fans create large recirculation zones in the river, or eddies, where sandbars form.

Research and monitoring have resulted in a better understanding of how sandbars and sand resources are affected by the operation of Glen Canyon Dam. For example, high-flow releases from the dam that simulate mild natural floods can modify or maintain debris fans, which control the location and regulate the size of sandbars (Webb and Griffiths, 2001).

Perhaps the single most important finding in the last decade is that relations between the discharge of water 


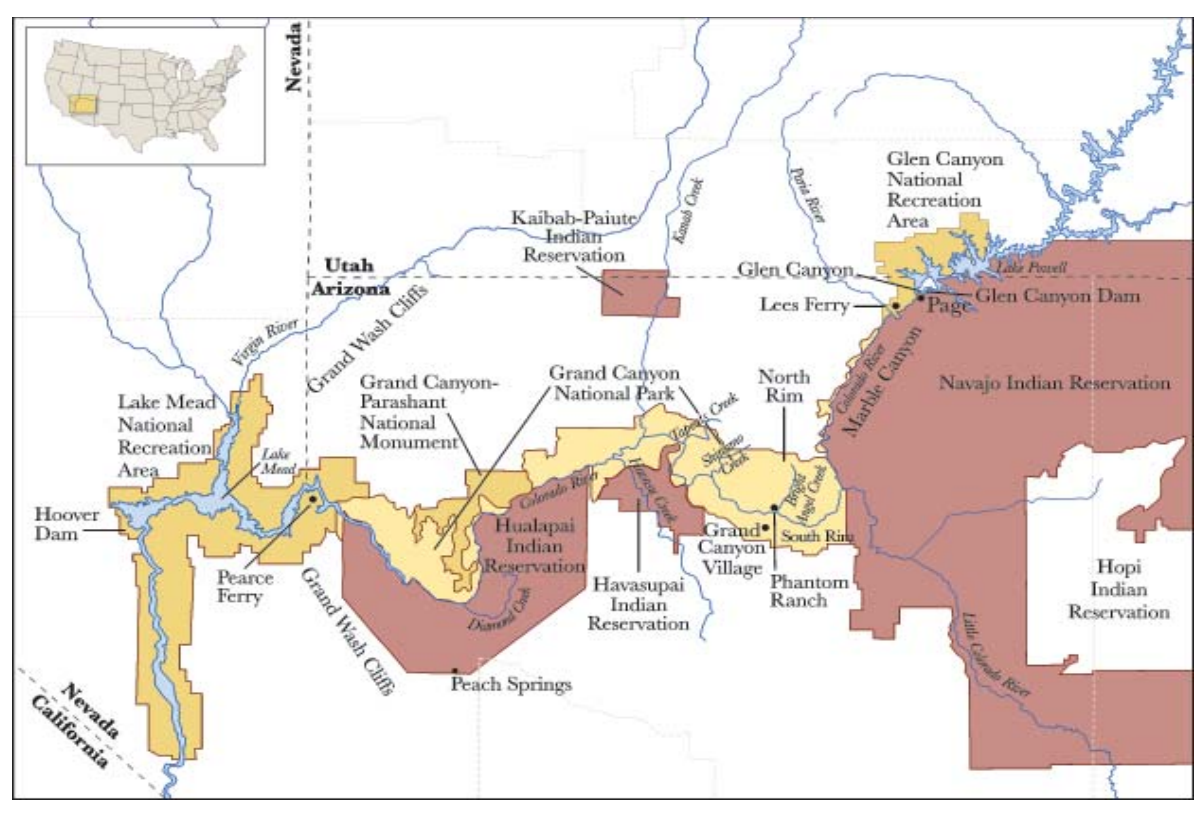

Figure 2. The Colorado River ecosystem encompasses the Colorado River corridor from Glen Canyon Dam to the western part of Grand Canyon National Park, where the river empties into Lake Mead. The maintenance of sand resources in the Colorado River ecosystem is a primary goal of the Glen Canyon Dam Adaptive Management Program.

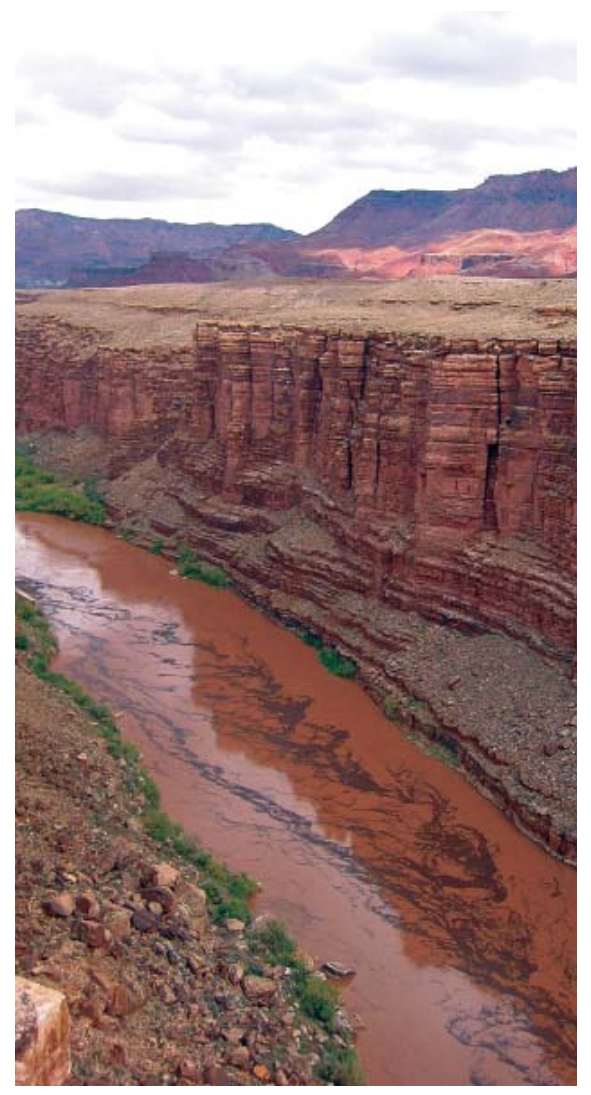

Figure 3. The Colorado River several miles downstream from its confluence with the Paria River during a flood. Paria floods dramatically affect sediment and organic loads in the Colorado River (USGS photograph by Theodore Kennedy). from the dam and sand transport change over time in the Colorado River (Rubin and others, 1998; Topping and others, 1999, 2000a; Rubin and Topping, 2001). Sand on the riverbed becomes finer when tributaries add fine sediment to the river and coarser when higher releases from the dam wash finer sand downstream. These changes in the grain size of sand affect the rate at which sand is transported downstream. As a result of dam operations and decreased sand supply, the Colorado River now typically transports more sand downstream than tributaries supply on a seasonal to annual basis (Topping and others, 2000b; Rubin and others, 2002; Wright and others, 2005). This sediment deficit has resulted in progressive erosion of channel and sandbar deposits from Marble and Grand Canyons since 1963 (Schmidt and others, 2004). This erosion of channel and sandbar deposits has continued despite constraints placed on releases from the dam by the 1996 Record of Decision (Rubin and others, 2002; Schmidt and others, 2004; Wright and others, 2005).

A second important finding is that during the high-flow releases in 1996 and 2000, the primary sources of sand for building high-elevation sandbars were the low-elevation parts of the same sandbars (Andrews and others, 1999; Schmidt, 1999; Hazel and others, 2006) and not sand that had accumulated on the riverbed, as had been hypothesized. During these two experiments, conducted when the Colorado River was relatively sand depleted (Hazel and others, 2006), the erosion of low-elevation sandbars actually resulted in a net reduction in overall sandbar size.

Maintenance of sandbar size requires high-flow releases from the dam to flush sand from the riverbed up onto sandbars (Schmidt and others, 1999). Recent research has shown, however, that tributary-supplied sand does not accumulate on the riverbed over multiyear periods under typical dam conditions (Topping and others, 2000b; Rubin and others, 2002; Wright and others, 2005). Because sand does not accumulate on the riverbed, there is generally insufficient sand available to be transferred from the riverbed to sandbars. This finding holds true even when the quantity of sand supplied by tributaries is above average, which was the case during the late 1990s. Additionally, the lower elevation parts of these eroded sandbars and the adjacent riverbed never fully recovered their former sand volume following the scouring that occurred during the 1996 high-flow release (Schmidt and others, 2004).

These results indicate that high-flow releases conducted under sand-depleted conditions, such as those that existed in 1996, will not successfully sustain sandbar area and volume. As understanding improved following the 1996 and 2000 experiments, scientists and managers focused on the need to strategically time high-flow releases to take advantage of episodic tributary floods that supply new sand to the Colorado River downstream from the dam.

\section{The Importance of Tributary Floods}

In November 2004, a high-flow release was timed to follow tributary floods for the first time on the Colorado River (fig. 4). This experiment resulted in an increase in sandbar total area and volume in the upper half of Marble Canyon (Topping and others, 2006). Further downstream, where sand was less abundant, a net transfer of sand out of eddies occurred that was similar to that observed during the 1996 and 2000 experiments (Hazel and others, 2006; Topping and others, 2006). Scientists also confirmed that substantial increases in total eddy-sandbar area and volume are only possible during high-flow releases that follow large tributary floods 
that enrich sand supplies in the main channel of the Colorado River (Rubin and others, 2002; Topping and others, 2006). However, more sand will be required than was available during the 2004 experiment (800,000 to $1,000,000$ metric tons) to achieve increases in total sandbar area and volume throughout all of Marble and Grand Canyons in the future (Topping and others, 2006).

\section{Preserving Archaeological Sites}

Many archaeological sites found near the Colorado River are buried by windborne sand that helps to preserve these sites over time. Sandbars created by the 2004 experiment increased the windborne transport of sand toward some of these archaeological sites in Grand Canyon (Draut and others, 2005; Draut and Rubin, 2006). Increased sand carried by the wind from restored sandbars may reduce erosion and increase the preservation potential at some archaeological sites.

\section{Managing Sand in the Future}

Recent findings suggest that it may be necessary to make more sand available for maintaining and restoring sandbars than is now provided by typical tributary flood events. One possibility is augmenting the sand available from tributaries with sand trapped behind Glen Canyon Dam (Randle and others, 2007). Alternatively, the sand supply might be indirectly increased through the use of short-duration high flows following each average to large tributary input of sand; this approach would move new sand from the riverbed to sandbars before it can be carried downstream (Topping and others, 2006). The effectiveness of this strategy rests on minimizing sand export and sandbar erosion during periods between high flows; however, export and erosion rates are strongly dependent on powerplant release volume and daily release patterns (Wright and others, 2005). Another possibility is constraining dam releases following tributary sand inputs for a period of time until a high-flow release can be carried out; however, constraining daily operations may not be possible during extended periods of above-average runoff into Lake Powell or when the reservoir is near capacity.

By Theodore S. Melis, David J. Topping, David M. Rubin, and Scott A. Wright
A.

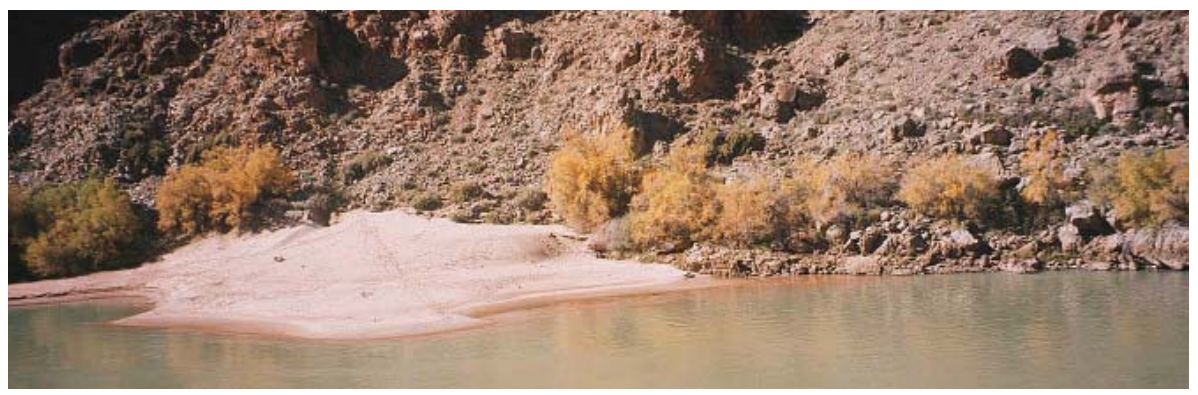

$B$.

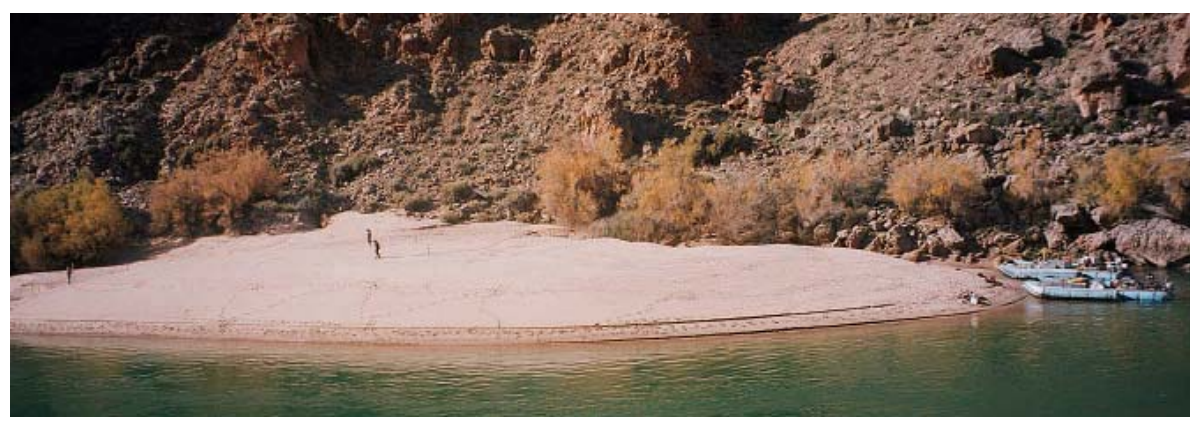

Figure 4. Repeat photographs of a sandbar along the left shore of the Colorado River near river mile 30 shortly before $(A)$ and shortly after $(B)$ the November 2004 high-flow experiment. Such substantial increases in sandbar volume and area are only possible when high flows are conducted following large tributary inputs of sediment. Photographs provided by Joseph E. Hazel, Jr.; Northern Arizona University.

\section{References}

Andrews, E.D., Johnston, C.E., Schmidt, J.C., and Gonzales, M., 1999, Topographic evolution of sand bars, in Webb, R.H., Schmidt, J.C., Marzolf, G.R., and Valdez, R.A., eds., The controlled flood in Grand Canyon: Washington, D.C., American Geophysical Union, Geophysical Monograph Series, v. 110, p. 117-130.

Draut, A.E., and Rubin, D.M., 2006, Measurements of wind, aeolian sand transport, and precipitation in the Colorado River corridor, Grand Canyon, Arizona - January 2005 to January 2006: U.S. Geological Survey Open-File Report 2006-1188, 88 p. [http://pubs.usgs.gov/of/2006/1188/].

Draut, A.E., Rubin, D.M., Dierker, J.L., Fairley, H.C., Griffiths, R.E., Hazel, J.E., Jr., Hunter, R.E., Kohl, K., Leap, L.M., Nials, F.L., Topping, D.J., and Yeatts, M., 2005, Sedimentology and stratigraphy of the Palisades, Lower Comanche, and Arroyo Grande areas of the Colorado River corridor, Grand Canyon, Arizona: U.S. Geological Survey Scientific Investigations Report 2005-5072, 68 p. [http://pubs.usgs. gov/sir/2005/5072].
Hazel, J., Jr., Topping, D.J., Schmidt, J.C., and Kaplinski, M., 2006, Influence of a dam on fine-sediment storage in a canyon river: Journal of Geophysical Research, v. 111, F01025, 16 p.

Patten, D.T., Harpman, D.A., Voita, M.I., and Randle, T.J., 2001, A managed flood on the Colorado River; background, objectives, design, and implementation: Ecological Applications, v. 11, no. 3, p. 635-643.

Randle, T.J., Lyons, J.K., Christensen, R.J., and Stephen, R.D., 2007, Colorado River ecosystem sediment augmentation appraisal engineering report: U.S. Bureau of Reclamation, Technical Service Center, Sedimentation and River Hydraulics Group, Denver, Colorado.

Rubin, D.M., Nelson, J.M., and Topping, D.J., 1998, Relation of inversely graded deposits to suspended-sediment grain-size evolution during the 1996 flood experiment in Grand Canyon: Geology, v. 26, p. 99-102. 
Rubin, D.M., and Topping, D.J., 2001, Quantifying the relative importance of flow regulation and grain-size regulation of suspended-sediment transport $(\alpha)$, and tracking changes in bed-sediment grain size $(\beta)$ : Water Resources Research, v. 37, p. 133-146.

Rubin, D.M., Topping, D.J., Schmidt, J.C., Hazel, J., Kaplinski, K., and Melis, T.S., 2002, Recent sediment studies refute Glen Canyon Dam hypothesis: EOS, Transactions, American Geophysical Union, v. 83, no. 25, p. 273, 277-278.

Schmidt, J.C., 1999, Summary and synthesis of geomorphic studies conducted during the 1996 controlled flood in Grand Canyon, in Webb, R.H., Schmidt, J.C., Marzolf, G.R., and Valdez, R.A., eds., The controlled flood in Grand Canyon: Washington, D.C., American Geophysical Union, Geophysical Monograph Series, v. 110, p. 329-341.

Schmidt, J.C., Andrews, E.D., Wegner, D.L., Patten, D.T., Marzolf, G.R., and Moody, T.O., 1999, Origins of the 1996 controlled flood in Grand Canyon, in Webb, R.H., Schmidt, J.C., Marzolf, G.R., and Valdez, R.A., eds., The controlled flood in Grand Canyon: Washington, D.C., American Geophysical Union, Geophysical Monograph Series, v. 110, p. 23-36.

Schmidt, J.C., and Graf, J.B., 1990, Aggradation and degradation of alluvial sand deposits, 1965 to 1986, Colorado River, Grand Canyon National Park, Arizona: U.S. Geological Survey Professional Paper 1493, 74 p.

Schmidt, J.C., and Rubin, D.M., 1995, Regulated streamflow, fine-grained deposits, and effective discharge in canyons with abundant debris fans, in Costa, J.E., Miller, A.J., Potter, K.W., and Wilcock, P.R., eds., Natural and anthropogenic influences in fluvial geomorphology: the Wolman volume: Washington, D.C., American Geophysical Union, Geophysical Monograph Series, v. 89, p. 177-195.
Schmidt, J.C., Topping, D.J., Grams, P.E., and Hazel, J.E., Jr., 2004, System-wide changes in the distribution of fine sediment in the Colorado River corridor between Glen Canyon Dam and Bright Angel Creek, Arizona: Grand Canyon Monitoring and Research Center final report [http://www.gcmrc. gov/library/reports/physical/Fine_Sed/ Schmidt2004.pdf].

Topping, D.J., Rubin, D.M., Nelson, J.M., Kinzel, P.J., III, and Bennett, J.P., 1999, Linkage between grain-size evolution and sediment depletion during Colorado River floods, in Webb, R.H., Schmidt, J.C., Marzolf, G.R., and Valdez, R.A., eds., The controlled flood in Grand Canyon: Washington, D.C., American Geophysical Union, Geophysical Monograph Series, v. 110, p. 71-98.

Topping, D.J., Rubin, D.M., Nelson, J.M., Kinzel, P.J., III, and Corson, I.C., 2000a, Colorado River sediment transport: pt. 2: systematic bed-elevation and grain-size effects of sand supply limitation: Water Resources Research, v. 36 , p. $543-570$.

Topping, D.J., Rubin, D.M., Schmidt, J.C., Hazel, J.E., Jr., Melis, T.S., Wright, S.A., Kaplinski, M., Draut, A.E., and Breedlove, M.J., 2006, Comparison of sediment-transport and bar-response results from the 1996 and 2004 controlled-flood experiments on the Colorado River in Grand Canyon, in Federal InterAgency Sedimentation Conference, 8th, Reno, Nevada, 2006, CD-ROM Proceedings (ISBN 0-9779007-1-1).

Topping, D.J., Rubin, D.M., and Vierra, L.E., Jr., 2000b, Colorado River sediment transport: pt. 1: natural sediment supply limitation and the influence of Glen Canyon Dam: Water Resources Research, v. 36, p. 515-542.
Topping, D.J., Schmidt, J.C., and Vierra, L.E., Jr., 2003, Computation and analysis of the instantaneous-discharge record for the Colorado River at Lees Ferry, Arizona, May 8, 1921, through September 30, 2000: U.S. Geological Survey Professional Paper 1677, 118 p. [http://pubs.water.usgs.gov/pp1677].

U.S. Department of the Interior, 1995, Operation of Glen Canyon Dam Final Environmental Impact Statement: Salt Lake City, Utah, Bureau of Reclamation, Upper Colorado Region, 337 p.

Webb, R.H., and Griffiths, P.G., 2001, Monitoring of coarse sediment inputs to the Colorado River in Grand Canyon: U.S. Geological Survey Fact Sheet 019-01, 4 p.

Wright, S.A., Melis, T.S., Topping, D.J., and Rubin, D.M., 2005, Influence of Glen Canyon Dam operations on downstream sand resources of the Colorado River in Grand Canyon, in Gloss, S.P., Lovich, J.E., and Melis, T.S., eds., The state of the Colorado River ecosystem in Grand Canyon: U.S. Geological Survey Circular 1282, p. 17-31.

\section{More Information}

Theodore S. Melis

U.S. Geological Survey

Southwest Biological Science Center

Grand Canyon Monitoring and Research Center 2255 N. Gemini Drive

Flagstaff, Arizona, 86001

Tel: 928-556-7094

E-mail: tmelis@usgs.gov

Web site: www.gcmrc.gov 